\title{
АЛІМЕНТАРНА ПРОФІЛАКТИКА ДИСТРЕСУ, ЯК РОЗДІЛ ДИСЦИПЛІНИ “ГІГІЄНА ТА ЕКОЛОГІЯ”, У СИСТЕМІ ПІДГОТОВКИ МЕДИЧНОГО ПСИХОЛОГА
}

T. І. Аністратенко

Наџіональниймедичний університет імені О. О. Богомольия

\section{NUTRITIONAL PREVENTION OF DISTRESS AS A PART OF THE DISCIPLINE "HYGIENE AND ECOLOGY" IN THE SYSTEM OF TRAINING OF MEDICAL PSYCHOLOGIST}

\section{T. I. Anistratenko}

\author{
National Medical University by O. O. Bohomolets
}

\begin{abstract}
Стрес є поліетіологічним і поліпатогенетичним чинником впливу на організм, який призводить до численних психосоматичних розладів. Володіння методами та засобами аліментарної корекції стресу та профілактики дистресу с обов'язковим у системі підготовки медичного психолога.
\end{abstract}

Stress is a polietiologic and polipathogenetic factor which affects the body and leads to numerous psychosomatic disorders. Knowledge of the methods and means of alimentary correction of stress and distress prevention is obligatory in the training of a medical psychologist.

Вступ. У практичній діяльності медичного психолога наслідки дистресу у пацієнтів посідають чільне місце і виявляються численними ознаками порушення психологічної рівноваги та психосоматичних розладів. Це $\epsilon$ проблема, з якою необхідно боротися не лише методами психологічного консультування, аі патофізіологічно обгрунтованими методами натуропатичної корекції. Цим зумовлена необхідність викладання відповідних розділів гігієни на медико-психологічному факультеті.

Основна частина. За сучасних уявлень, стрес $\epsilon$ не лише чинником впливу на нейроендокринну систему з відповідними реакціями з ії боку, як описував Г. Сельє, а визначається як поліетіологічне і поліпатогенетичне явище. Людство постійно перебуває під впливом соціально-економічних катаклізмів та політичних подій, екологічних природних та техногенних катастроф, а також особистих, виробничих, побутових, навчальних та інших стресогенних чинників. Зазнає стресу кожна людина незалежно від іï посади, положення в суспільстві й матеріального статку.

Медичні психологи повинні вміти оцінювати реальну небезпеку цих явищ для своїх пацієнтів і ії наслідки для психологічного і психосоматичного статусу.

За статистичними даними, в США (країні, яка першою усвідомила проблему стресу) 90 \% населення постійно перебуває у стані сильного стресу. Із них
$60 \%$ зазнають стресу 1-2 рази на тиждень, $30 \%$ майже кожного дня. Вчені відзначили, що 67 \% візитів до лікаря спричинені стресіндукованими симптомами. Чимало великих корпорацій витрачають сотні мільйонів доларів на медичну допомогу через захворювання, спровоковані стресом. У результаті економічні втрати від стресу у США перевищують 300 млрд доларів щорічно [ 1 ].

За статистичними спостереженнями, 40 млн iз 147 млн працівників у країнах Свропейського Союзу страждають від стресів, а це щорічно обходиться суспільству в 19 млрд доларів США. Чимало мешканців країн “Великої Свропи” страждають від психосоматичних розладів, які оцінюються фахівцями як наслідки хронічних стресових ситуацій. Так, 13 \% скаржаться на постійний головний біль, 17 \% - на м'язові болі, ще 30 \% мають неприємні відчуття й болі в ділянці спини. За результатами соціологічних опитувань, стрес справляє сильний негативний вплив на сексуальне життя $60 \%$ людей.

В Україні за оцінками фахівців, проведеними у 2010 році, майже $70 \%$ населення постійно перебуває у стані стресу, $30 \%$ - у стані сильного стресу [2].

Хронічний стрес призводить до виснаження адаптаційних механізмів, розвитку дистресу і, як наслідок, синдрому хронічної втоми. 
Розрізняють 2 типи реакціїорганізму на стрес: фізіологічна іпсихоемоційна. Фізіологічна реакція на стрес - соматопсихічна реакція організму на об'єктивні зміни умов життедіяльності людини. Стресорними чинниками можуть бути природні, антропогенні та техногенні чинники (мікроклімат, радіація, шум, висока та низька температура, вібрація, стихійні лиха, аварії, катастрофи) та інші зовнішні фізичні і хімічні фактори.

Психоемоційна реакція на стрес-психосоматична нервово-ендокринна реакція організму на об'єктивні зміни умов життєдіяльності, або вплив стресогенного чинника, обумовлена індивідуальною особистісною позицією індивіда. Людина реагує на ситуацію та інтерпретує ії залежно від особистих характеристик, соціального статусу, поведінки, віку, вихованості, життєвого досвіду [3].

Під час практичних занять ми акцентуємо увагу майбутніх психологів на діагностичних критеріях стресу та дистресу, які поділяються на 4 групи: психосоматичні, поведінкові, емоційні та інтелектуальні [4].

До психосоматичних симптомів стресу відносять нейровегетативні дисфункції (підвищення або зниження артеріального тиску, прискорений або неритмічний пульс, прискорене дихання, біль у грудях, тремор рук, судоми, тремтіння голосу, підвищена пітливість), порушення процесів травлення та функцій ШКТ (підвищений або знижений апетит, холестаз, закрепи, діарея, гіперперистальтика, метеоризм), швидке збільшення або втрату маси тіла, напруження в м'язах, болі в шиї, спині, головний біль, бруксизм, нейроалергодерматити, зниження імунітету, згущення крові, часті нездужання, порушення сну (неспокій або безсоння, погані сновидіння, кошмари), стомлюваність, кволість, прискорену або уповільнену мову.

До поведінкових ознак стресу відносять порушення харчової поведінки (втрата апетиту або переїдання, булімія), конфліктність на роботі та в сім'ї, обмеження спілкування з близькими і друзями, неувага до зовнішнього вигляду, антисоціальна поведінка, більш інтенсивне куріння і вживання алкоголю, неконтрольовані рухи.

До емоційних симптомів стресу відносять нав'язливі негативні думки, занепокоєння, підвищену тривожність, підозрілість, похмурий настрій, відчуття постійної туги, депресію, дратівливість, напади гніву, емоційну “тупість”, байдужість, відчуття відчуженості, самотності, цинічний, недоречний гумор, невпевненість у собі, зниження самооцінки, почуття провини або невдоволення собою, своєю роботою, життям, втрату інтересу до різних його сфер.
Інтелектуальні ознаки стресу характеризуються порушенням логіки, незосередженістю, погіршенням пам'яті та розумової працездатності, низькою продуктивністю діяльності, акцентуацією навколо однієї проблеми, труднощами у прийнятті рішень (тривалі вагання або поспішність і необгрунтованість рішень), пасивністю, бажанням перекласти відповідальність на когось іншого, хронічною нестачею часу.

Особливу увагу приділяємо механізмам виникнення психосоматичних розладів та захворювань, які $\epsilon$ безпосереднім наслідком декомпенсації і дистресу. В результаті частого психоемоційного збудження активізується гіпофіз, гіпоталамус, надниркові залози, виділяється адреналін, як наслідок - підвищуються пульс, артеріальний тиск, частота дихання, в крові збільшується рівень ЛПНЩ та ТГ. Жир відкладається на внутрішній поверхні стінки судин. Згодом там утворюється сполучна тканина, накопичується кальцій. На цих ділянках звужується просвіт судин, погіршується їх пружність, розвиваються атеросклероз, гіпертонічна та ішемічна хвороба.

Нейростимуляція обкладових клітин шлунка при стресі призводить до виділення шлункового соку незалежно від наявності їжі, що провокує ерозії, виразки шлунка, дванадцятипалої кишки, порушення травлення, гіпомоторний та виразковий коліт.

Звуження судин, погіршення кровопостачання, кисневе голодування клітин мозку, що відбувається при затяжному хронічному стресі, індукують головний біль, мігрень, синдром хронічної втоми, безсоння, неврози, депресії та інші симптоми психоневрологічних розладів.

Сечостатева система реагує на дистрес пригніченням функції нирок, запаленням сечового міхура, порушенням гормонального статусу та репродуктивних функцій у чоловіків та жінок (порушенням менструального циклу, безпліддям у жінок, утрудненням ерекції, передчасним сім'явипорскуванням, зниженням активності сперматозоїдів, імпотенцією).

Тривалепсихоемоційне напруження характеризується пригніченням активності імунозахисних систем та механізмів, підвищенням неспецифічної захворюваності [ 5 ]. Безпосередніми наслідками хронічного стресу $є$ порушення аліментарного статусу, яке супроводжується активацією катаболізму білків і жирів, порушенням білкового обміну, виникненням полінутріснтного дефіциту, який поглиблює соматичні проблеми та активує соматопсихічні розлади. Як наслідок виникає порочне коло - стрес призводить до аліментарного дефіциту, а аліментарний дефіцит поглиблює стрес (рис. 1) [6]. Розуміння цього питання $є$ обов'язковим у формуванні професійних навичоклікарів-медичних психологів. 
Puc. 1. Порочне коло виникнення дистресу та супутнього аліментарного дефіциту.

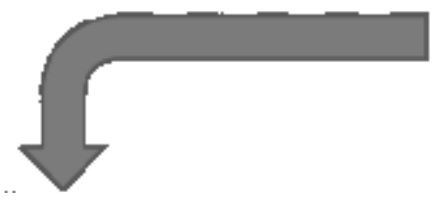

Викид великих доз адреналіну

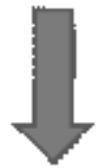

Підвищення обміну речовин, катаболізм білків, жирів

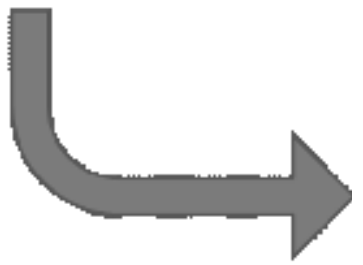

Підвищення потреби у білках,

ПНЖК $\omega 3$, вітамінах групи В, C, E, А, кальції, магнії, селені

\section{CTPEC}

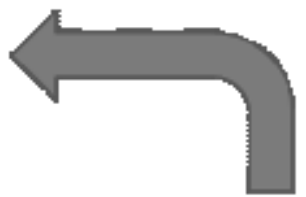

Роздратованість, безсоння, зниження концентрації уваги, послаблення імунітету, депресія

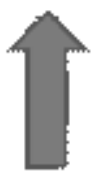

Дефіцит вітамінів групи В, С, E, А

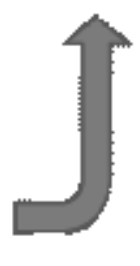

Враховуючи механізми формування патологічних змін в організмі при хронічному стресі, ми обгрунтовуємо принципи та засоби їх аліментарної профілактики та корекції. 3 цією метою в розділі “Гігієна харчування” введене поняття “психонутрієнтологія”, яке включає обгрунтування впливу відповідних нутрієнтів, продуктів харчування, пряно-ароматичних рослин на соматичний та психічний статус, що суттево доповнює знання студентами раціонального харчування. Сформульовані основні принципи антистресової дієти:

- Забезпечення раціонального адекватного харчування.

- Дотримання режиму харчування.

- Вилучення з раціону продуктів, які підвищують лабільність нервової системи.

- Забезпечення раціону продуктами, які $€$ переважними джерелами нутрієнтів, які підвищують стресрезистентність.

- Індивідуальна корекція дієти за допомогою пряно-ароматичних рослин.

- Фітонутрієнтна корекція раціону.

Робиться акцент на специфічне значення окремих нутрієнтів у корекції психосоматичних розладів.

Роль нутрієнтів у механізмах підвищення стресостійкості вивчалася російськими фахівцями Університету дружби народів, професорами С. В. Орловою i Л. С. Василевською та закордонними авторами (Генріх Мейроуз) [6, 7]. Вони визначили роль нутрієнтів у патогенезі дистресу, зокрема:

Білки $є$ джерелами есенціальних амінокислот, які беруть участь в анаболічних та регуляторних процеcax: гістидин - попередник гістаміну, покращує діяльність ЦНС; гліцин - медіатор гальмівного типу дії; глутамін - амінокислота, яка перетворюється в глютамінову кислоту, підвищує рівень гамма-аміномасляної кислоти, необхідної для нормальної мозкової діяльності і розумової активності, входить до складу глутатіону, в нейронах бере участь в транспорті іонів калію, аміногруп і зв'язуванні аміаку; тирозин бере участь у синтезі адреналіну, гормонів щитоподібної залози; треонін - регулює передачу нервових імпульсів медіаторами в мозку; триптофан - попередник серотоніну; фенілаланін регулює роботу щитоподібної залози, бере участь у синтезі адреналіну $\mathrm{i}$ норадреналіну, є природним антидепресантом; холін - субстрат для синтезу ацетилхоліну у мозку; цистеїн - входить до складу глутатіону, необхідний для засвоєння селену.

Жири беруть безпосередню участь у формуванні нервових тканин та клітин і регуляції функцій мозку. Зокрема, фосфоліпіди (фосфатидилхолін та фосфатидилсерин) формують сфінгомієлінові волокна нейронів мозку, ПНЖК - w-3 - активують синтез простациклінів, які забезпечують профілактику атеросклерозу і тромбоутворення у судинах мозку.

Важлива роль у нормалізації психосоматичного статусу належить вітамінам:

Вітаміни групи В сприяють нормальному функціонуванню нервової системи, підвищують стійкість до стресів, депресій, втоми. Беруть участь у процесах енергозабезпечення, в метаболізмі жирів, білків і вуглеводів, нормалізують роботу серцево-судинної системи, печінки, шлунка, кишечника. Вітамін $\mathrm{B}_{1}$ (тіамін) називають “вітаміном оптимізму”, необхідний для 
нормальної передачі нервових сигналів; вітамін $\mathrm{B}_{2}$ (рибофлавін) бере участь у синтезі кортикостероїдів, глікогену, відновленні глютатіону, прискорює перетворення, регулює стан центральної і периферичної нервової системи; вітамін В 3 (ніацин) регулює синтез серотоніну, підсилює гальмівні процеси, сприяє насиченню клітин мозку киснем, нормалізації сну; вітамін $\mathrm{B}_{5}$ (пантотенова кислота) регулює роботу надниркових залоз, бере участь в обміні холестерину, кортикостероїдів, синтезі антитіл; вітамін В 6 (піридоксин) бере участь у синтезі серотоніну; фолієва кислота (вітамін $\mathrm{B}_{9}$ ) необхідна для синтезу серотоніну і норадреналіну; вітамін $\mathrm{B}_{12}$ (ціанокобаламін) бере участь в утворенні мієлінової оболонки нервів та процесах нервової провідності.

Біотин (вітамін Н) забезпечує нервові клітини енергією, бере участь у синтезі глікокінази - ферменту, який “запускає” обмін глюкози у нервових клітинах. Біотин покращує роботу нервової системи, знижує симптоми невропатії, знижує вміст цукру в крові.

Вітамін С депонується у надниркових залозах і при стресі його запас виснажується, тому потреба підвищується.

Вітамін Е (токоферол) забезпечує антиоксидантний захист, регулює насичення тканин киснем, захищає надниркові залози, нормалізує роботу печінки, бере участь в синтезі фосфатидилхоліну, який відіграє важливу роль у функціонуванні мозку і всієї нервової системи. Вітамін А (ретинол) є синергістом вітаміну Е, мобілізує залізо з депо та сприяє оксигенації тканин.

Акцентуємо увагу студентів на роль мінеральних речовин у специфічних механізмах нейрорегуляції і нейропротекції. Зокрема, кальцій забезпечує рівновагу між процесами збудження і гальмування в корі го-

\section{Лiтература}

1. Sauter SL, Murphy LR, Hurrell JJ, Jr. [1990]. Prevention of work-related psychological disorders. American Psychologist 45(10):1146-1158.

2. Статистика стресcа. - www.lossofsoul.com

3. Скрипченко О. В. Загальна психологія / О. В. Скрипченко, Л. В. Долинська, 3. В. Огороднійчук. - Київ : Каравела, 2009. - 464 c.

4. Щербатых Ю. В. Психология стресса и методы коррекции /Ю.В. Щербатых.-Санкт-Петербург :Питер, 2008.-256с. ловного мозку, бере участь у передачі нервових імпульсів, скороченні м'язів; магній сприяє засвоєнню кальцію і калію, підсилює процеси гальмування в корі головного мозку, забезпечує заспокійливий, антиспастичний, судинорозширюючий, діуретичний ефекти; калій регулює серцевий ритм, водний баланс організму, сприяє повноцінному м'язовому скороченню, проникненню поживних компонентів через клітинні мембрани; селен забезпечує потужну антиоксидантну дію, підсилює антиоксидантну ефективність вітаміну Е i разом з ним уповільнюють процеси вільнорадикального окислення ліпідів тканин; йод необхідний для синтезу гормонів щитоподібної залози, розвитку і функціонування головного мозку і нервової системи, підтримки розумової працездатності та пам'яті.

У розділі “Гігієна харчування" ми детально розбираємо всі джерела нутрієнтів і обгрунтовуємо включення окремих харчових продуктів у відповідних поєднаннях в стрескорегуючу дієту.

Висновки: 1. Стрес є поліетіологічним і поліпатогенетичним процесом, який впливає на нейроендокринні структури і призводить до психосоматичних розладів у діяльності серцево-судинної, нервової систем, шлунково-кишкового тракту, обмінних процесів.

2. Реакція організму на хронічний стрес супроводжується виснаженням депо відповідних вітамінів та мікроелементів, які беруть участь у механізмах стресадаптації, що призводить до супутнього полінутрієнтного дефіциту та поглиблює наслідки дистресу.

3. У методиках профілактики і корекції дистресу необхідно застосовувати патогенетично обгрунтовані засоби аліментарної корекції, що сприятиме підвищенню адаптаційних можливостей організму і відновленню фізичного і психологічного гомеостазу.

5. Сандомирский М. Е. Защита от стресса. Телесные технологии / М. Е. Сандомирский. - Санкт-Петербург : Питер, 2008.-256 c.

6. Орлова С. В. Нутрициальные подходы к профилактике и лечению стресса : учебно-методическое пособие / С. В. Орлова, Л. С. Василевская, Л. И. Карушина. - М. : ООО “ПолиграфТехСервис", 2002.-43 с.

7. Мейроуз Г. Нутрицевтика как метод пихокоррекции / Г. Мейроуз. - Москва : Профит Стайл, 2009. - 256 с. 